\title{
RECORD OF THE CERATIOID FISH, LINOPHRYNE LUCIFER, IN THE NW ATLANTIC
}

\author{
LINOPHRYNE LUCIFER, GEĘINOWA RYBA \\ Z PÓENOCNO-ZACHODNIEGO ATLANTYKU
}

\author{
From Department of Ichthyology \\ Head: Prof. Dr. Eugeniusz Grabda
}

This paper describes a rare specimen of deep-sea angler-fish, Linophryne lucifer, collected from a depth of about 400 metres on the NW Flemish Capfishing-ground of the NW Atlantic. December 10, 1965; $255(209+46) \mathrm{mm}$. in total length, $1.00 \mathrm{~kg}$. in weight.

On the $10^{\text {th }}$ of December 1965, during fishing for redfishes at the NNW Flemish Cap (ICNAF-area $5 z$ ) of the NW Atlantic, a single female of Linophryne lucifer Collett, 1886 was caught in the bottom trawl from a depth of about 400 metres. The fish showed slight contractions of the body after being taken out of the bottom trawl, with the exception of the tail portion from which significant convulsions of the skeletal muscles were observed. It was soon noticed, the fish gave off a rich specific odour, that could be detected later in frozen condition too.

Although the species is the type of the genus, it is known as heretofore on the 7 female specimens (Collett 1886, Brandes and Kotthaus 1960, Krefft 1963, Wallershaus 1963, Bertelsen and Krefft 1965). Among the references especially underlined must be Bertelsen and Krefft's paper of 1965, that gives the views of the bibliography; the redescription of the species in details, its variability, distributional remarks and a map of the localities of capture. Quoted date we can see in Regan and Trewavas 1932, Fowler 1936, Bertelsen 1951 and others.

Countings and m e a s u rements. - Dorsal rays 3; pectoral rays 16; caudal with 9 rays (four among them are bifid while the remaing are straight, two at dorsal and three at ventral margins; ventral marginal ray is rudimentary, still completely lying under skin); all fin rays flexible; branchiostegals 5 . 


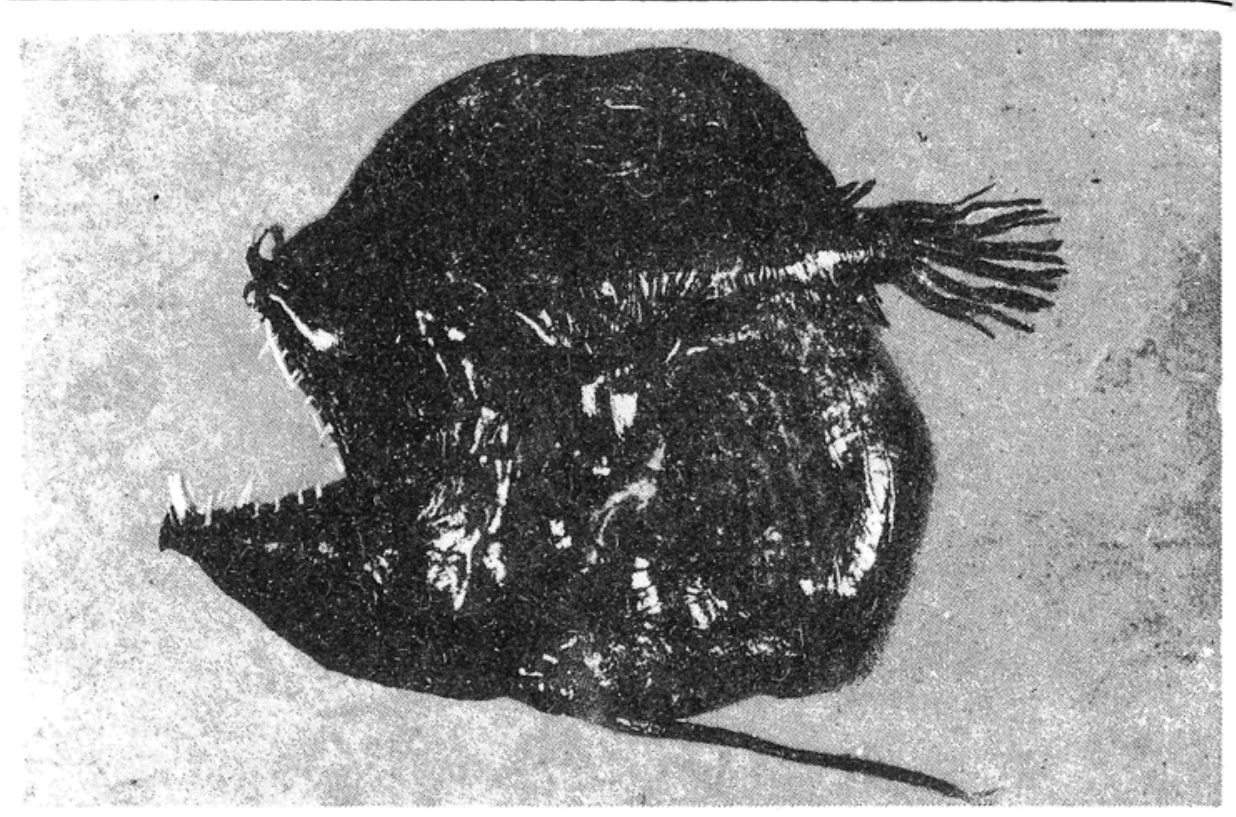

Fig.1. Linophryne lucifer Collett, 1886

An adult female (Fig.1) with a total length of $255 \mathrm{~mm}$ (with nearly closed mouth) and anal origin to caudal base of $32 \mathrm{~mm}$., the ratio being $0.12 \mathrm{TL}$; standart length (measured from tip of snout to caudal base at open mouth) of $193 \mathrm{~mm}$.; depth of body (measured at barbel origin) of $152 \mathrm{~mm}$.; depth of caudal peduncle of $22 \mathrm{~mm}$.; head length from snout anterior margin to tip of preopercular spine of $115 \mathrm{~mm}$.; measure from anterior margin of the lower jaw (with independently open mouth) to tip of preopercular spine amounts to $143 \mathrm{~mm}$.; head depth (at sphenotic spine altitude) of $145 \mathrm{~mm}$.; snout length of $32 \mathrm{~mm}$.; orbit diameter of $4 \mathrm{~mm}$.; premaxillare length of $6 \mathrm{~mm}$.; lower jaw length of $100 \mathrm{~mm}$.; predorsal length (measured from tip of snout) is $175 \mathrm{~mm}$. whereas measure from anterior margin of the lower jaw (at independently open mouth) to front of dorsal fin amounts to $214 \mathrm{~mm}$. ; dorsal base length of $9 \mathrm{~mm}$.; dorsal height from 22 to $24 \mathrm{~mm}$.; pectoral length of $25 \mathrm{~mm}$.; caudal length of $56 \mathrm{~mm}$; ; distance from tip of snout to barbel base (with open mouth) of $137 \mathrm{~mm}$.; distance from lower jaw anterior margin to barbel base of $135 \mathrm{~mm}$.; sphenotic spine length of $6 \mathrm{~mm}$.; frontal fang length of $19 \mathrm{~mm}$.; posterior teeth are about $7 \mathrm{~mm}$.; accessory teeth length from 3 to $5 \mathrm{~mm}$.; illicium length of $21 \mathrm{~mm}$.; barbel total length of $170 \mathrm{~mm}$.; width of barbel in bulbiform portion is $15 \mathrm{~mm}$.; barbel terminal dividers length of about $10 \mathrm{~mm}$.; tubercles at posterior end of barbel (on dividers and part of stem) are collocated on about $20 \mathrm{~mm}$. longitude; stomach is $120 \times 190 \mathrm{~mm}$. in measure; total length of intestine is $500 \mathrm{~mm}$.; diameter of intestine is $25 \mathrm{~mm}$. in anterior loop, from 10 to $12 \mathrm{~mm}$. in posterior section, and the rectum $5 \mathrm{~mm}$.; gall bladder is about $35 \mathrm{~mm}$. in diameter; dimension of urinary bladder is $34 \times 6 \mathrm{~mm}$.; of paired ovary length is $63 \mathrm{~mm}$. and its extremal wiath is of $22 \mathrm{~mm}$. ; measurement of "visceral sack" was $140 \times 200 \mathrm{~mm}$. 
Description. - The body is relatively short, compressed, with a very large head, and the abdomen heavy bulged. Sphenotic spines directed upwards and slightly slanting backwards, with clea-cut protuberance at their root on the outer side. The mouth is bevelled, especially wide, directed upwards. Lower jaw protruded, with a distinctive distension at the spot of dentaries accretion. Simultaneously there is a notch in front of the upper jaw. As seems likely, the mouth is

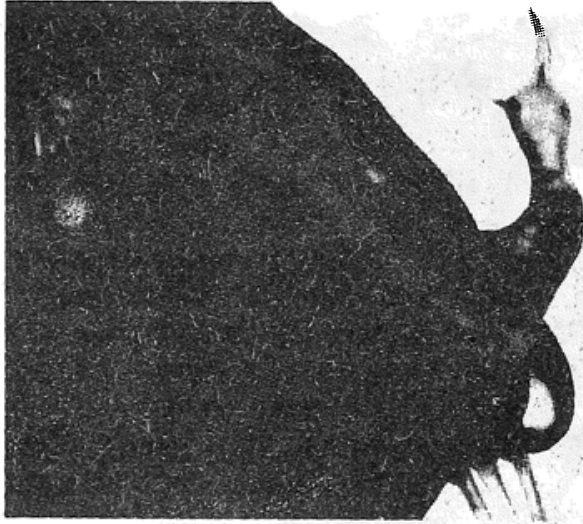

Fig.2. Linophryne lucifer; lateral view of illicium

never closed on account of the frontal fangs length. Frontal teeth are long and slender, assymetrically inserted, somewhat slanting backwards and inwards, whereas back teeth are shorter, all with distinct spaces between each of them. Each half of the upper jaw bears 11 teeth while on the right half of mandibular ramus are 9 teeth and 10 on the left. The upper pharyngeals curved backwards, numbered with a serie of 4 solid teeth on each side. There are 3 teeth on the vomer - one of them in front and two behind.

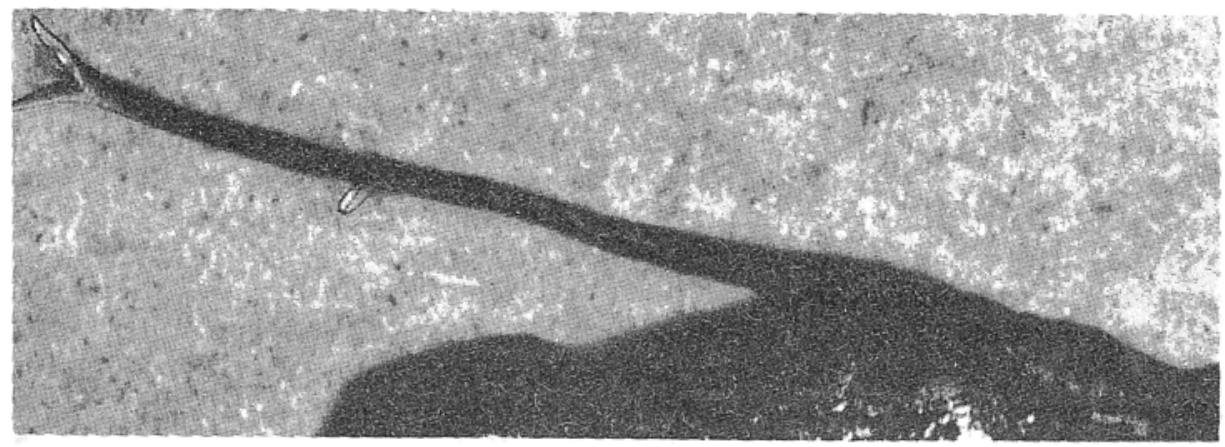

Fig.3. Linophryne lucifer: hyoid barbel

The illicium (Fig.2) originating as a single stem from the basal projection, which still completely lies under skin in a cranial groove. A stem nearly as long as one third of basal projection. A bulb of illicium, so-called esca (Bertelsen,s name, 1951) about one and half of eye in diameter, and near twice in stem length; it is pear-shaped, translucent, and contains a light gland inside with a globular lens as additional organ. Photographic illustration of the esca is shown in Fig. 2 .

The barbel (Fig.3) is bifid at the end, it appears bulbiformly from the center of the throat and consits of a single stem with a pair of lateral bran- 


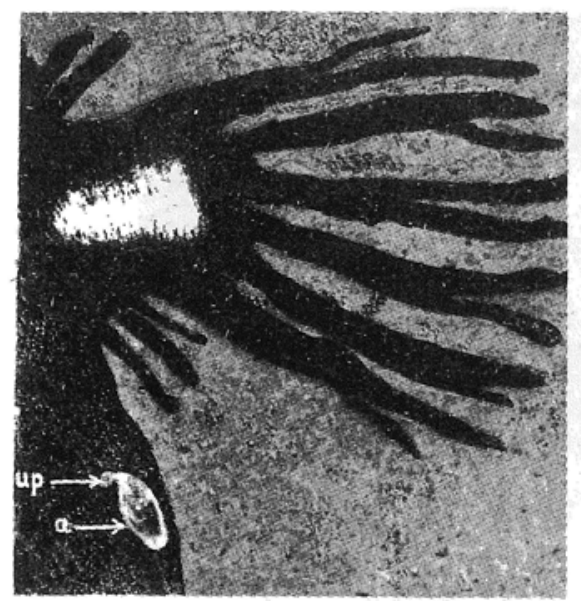

Fig.4. Linophryne lucifer: tail with dorsal, caudal and anal fins : urinary papilla and anus' openings well-advised by the arrows chlets on 2/3 length. Terminal dividers and lateral branchlets of the barbel are translucent and furnished with minute, transverse rounded tubercles arranged in unconspicuous series on the margins. Within the stem of barbel there is a structure being identified by Bertelsen (1951) as a sensory nerve in Linophrynids; its separate shunts running to each of terminal tubercle in.

The whole of the skin is quite smooth and opalescent. All spines of the head, the accessory teeth and the upper pharyngeals are completely covered with skin while the vomerine teeth and teeth of the main series are covered at the base only.

Four minute-sized skin-flaps, the third of which has two lateral embranchments, are situated on the abdomen nearby anus. I dare say, the skin-flaps may well be the positions of males fixation (?).

The colour. - Skin coloration is black with brownish undertone, except for barbel and illicium translucent details that are greyish.

The viscera (Fig.4), with exception of the kidneys, were closed into a thick-walled "visceral sack" being internally covered with parietal peritoneum of blackcolour, while the underskin tissue of gelatinous consistence was overlying. The veryextensible stomach fulfills most of the abdominal cavity; it opens at its postero-dorsal into the intestine forming a solid sphincter at the transition to intestine. The anterior intestine turns right and then left to join the rectum by a vulvular opening. The liver forms no lobes but it reaches as far as anterior intestine loop. The gall bladder filled with greenish-yellow secretion. Urinary bladder tubular. Urinary duct opens on a papilla behind of the anus, which is dislocated on the left side (Fig.5). A thick exudate of milk-cream colour has been ascertained in the abdominal cavity.

Food. - Some fish scales were found in the stomach and wholly digested yellowish mass appeared in the intestine. 


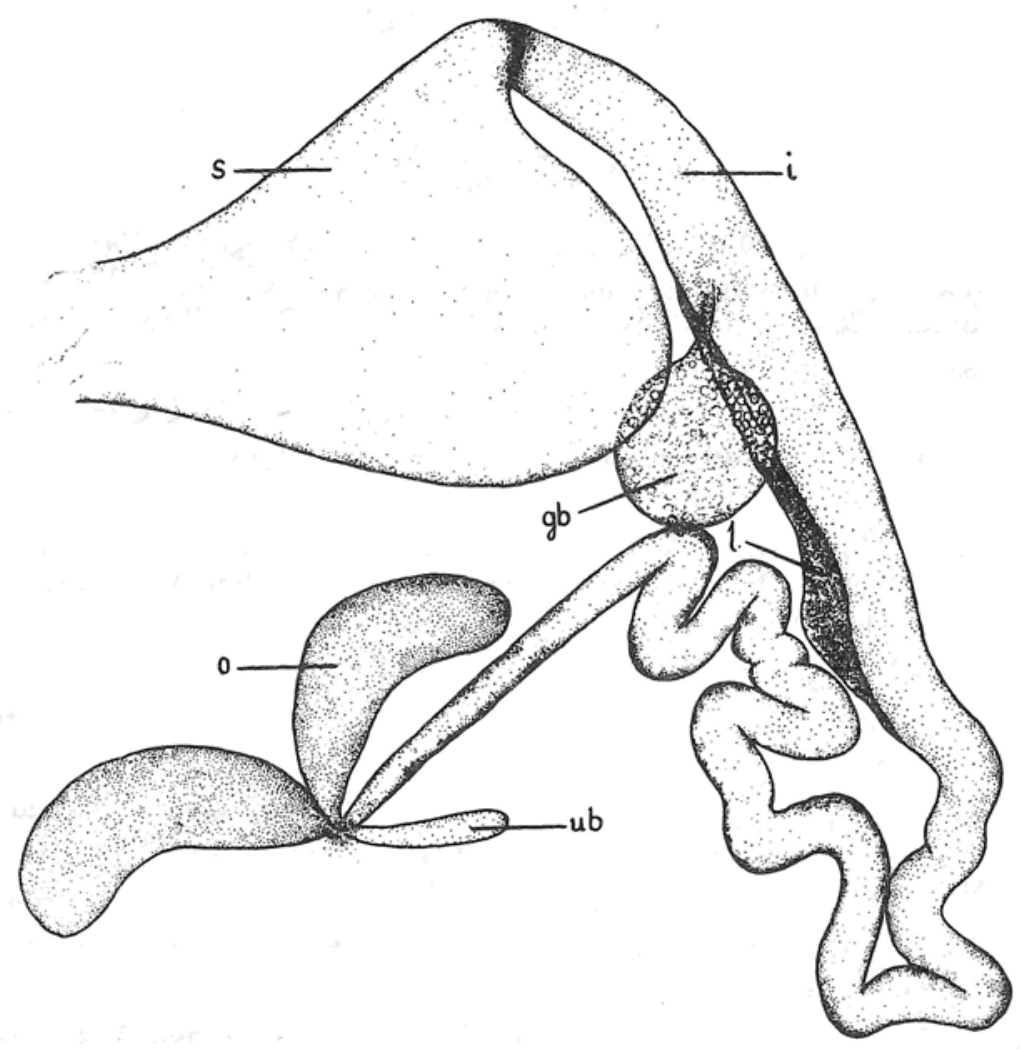

Fig.5. Linophryne lucifer; viscera of adult female: s - stomach, i - intestine, gb - gall bladder, o - ovaries, ub - urinary bladder, 1 - liver

\section{ACKNOWLEDGEMENT}

This rare specimen of deep-sea angler-fish was kindly given to me for description by my Col. Witold Gregrowicz, M.Sc., Eng., the technologist on board of $\mathrm{m} / \mathrm{t}$ "Feniks", to whom I have the pleasure to express my best thanks. Particularly cordial gratitude is due Dr. Erik Bertelsen, Director of Danmarks Fiskeri - og Havundersфgelser, Charlottenlund, for looking over the paper before it was printed and his friendliness comment on it, of great help in claryfying my thoughts on the subject. I gratefully acknowledge Professor Walerian Cięglewicz, President of the International Council for Exploration of the Sea, for his kind interest and helpful suggestions. Also, I am indebted to Professor Józef Popiel, Sea Fishery Institute, Gdynja, for providing valuable criticism of this manuscript. I should like to offer sincere thanks to my Cheef, Professor Eugeniusz Grabda, for constant guidance and 
valuable advice and enrouragement. Photographic illustrations are made by Jan Jerzy Pollesch, Agricultural College, Olsztyn.

\title{
REFERENCES
}

B e rte l s e n E., 1951: The Ceratioid Fishes; Ontogeny, Taxonomy, Distribution and Biology. - The Carlsb. Found. Oceanogr. Exped. Round the World 1928-30 and Prev. "Dana"-Exped., Dana-Report No. 39. Co. penhagen.

Bertelse $\mathrm{n}$ E. and $\mathrm{Krefft}$ G., 1965: On a Rare Ceratioid Fish, Linophryne lucifer Collett, 1886. - Vidensk. Medd. fra Dansk naturh. Foren., 128.

B randes C. H. and K otth a u A., 1960: Rare Fishes; Germany; B. Records of the Institut für Meeresforschung and the Abteilung Fischereibiologie der Biologischen Anstalt Helgoland, Bremerhaven. - Cons. Perm. Intern. Expl. Mer; Ann. biol. 15 (1958).

C o 11 e t t R., 1886: On a new Pediculate Fish from the Sea off Madeira. - Proc. Zool. Soc., London.

F o w 1 e $r$ H.W., 1936: The Marine Fishes of West Africa. Based on the Collection of the American Museum Congo Expedition, 1909-1915. - Bull. Am. Mus. Nat. Hist. LXX, 2, New York.

K r eff t G., 1963: Rare Fish; Germany. - Cons. Perm.Intern.Expl.Mer ; Ann. biol. 18 (1961).

R e gan C.T. and T rew a vas E., 1932: Deep-Sea Angler-Fishes (Ceratioidea). - The Carlsb. Oceanogr. Exped. Round the World 1928-30. Dana-Report No.2. Copenhagen.

W e 1 le rs ha u S., 1963: Über zwei Tiefseefische in der marinbiologischen Sammlung des Instituts für Meeresforschung in Bremerhaven: Linophryne lucifer Collett und Trigonolampa miriceps Regan and Trewavas. - Veröffentl. Inst. Meeresforsch. Bremerhaven.

\section{LINOPHRYNE LUCIFER, GEEBINOWA RYBA} Z PÓ̇NOCNO-ZACHODNIEGO ATLANTYKU

\author{
Streszczenie
}

Linophryne lucifer, rzadki gatunek ryby głębinowej pochodzący z łowiska Flemish Cap (rejon 5z ICNAF) na Atlantyku północno-zachodnim, opisany na podstawie pojedynczegc okazu samicy wyłowionej z głębokości około 400 metrów. Osobnik o długości $255(209+46) \mathrm{mm}$ i ciężarze 1,00 kg charakteryzuje się następującymi cechami: 11 zębów po obu stronach szczęki górnej; na szczęce dolnej - 9 zębów po stronie prawej i 10 po stronie lewej; 3 zęby le- 
mieszowe; zęby górnogardzielowe łukowato zagięte ku tyłowi, rozmieszczone po $4 \mathrm{w}$ jednym szeregu na obu kościach pharyngeale; kolce nadoczne skierowane ku tyłowi, z guzkiemw części nasadowej; szczęka dolna nieco dłuższa od 1/3 długości całkowitej; illicium stanowi mniej więcej 1/12 długości tułowiowej; eska jest 1,5 razy większa od średnicy oka, oprócz przydatków szczytowych posiada dwie pigmentowane wypustki boczne a wewnątrz zawiera gruczoł świetlny z okrągława soczewką: "barbel" stanowi 2/3 długości całkowitej, jest rozdwojony na końcu oraz zaopatrzony na około $2 / 3$ swojej długości w dwie gałązki boczne; wszystkie odgałęzienia, zarówno końcowe jak i boczne są przezroczyste, koloru szarawego, wyposażone w drobne, białawe brodawki ustawione w pojedynczych szeregach; skóra koloru czarnego $z$ odcieniem brunatnym.

LINOPHRYNE LUCIFER, ГЛУБОКОВОДНАЯ РЫБА ИЗ СЕВЕРО-ВОСТОЧНОЙ АТЛАНТИКИ

P е 3 ю 10

Linophryne lucifer, редкий вид глубоководной рыбы, выловленной у Флемиш Капа в северо-восточной Атлантике, описанный на одном экземпляре самки, добытой с глубины окого 400 метров. Образец длиной в 225 мм. и весом 1,00 кг., в основном имеет следующие характерные признаки: 11 зубов по обеим сторонам горной челюсти, на нижней челюсти - 9 зубов с правой и 10 с левой стороны; 3 зуба на вомере; фарингеальные зубы к зади изогнутые,распределены в двух рядах по 4 в каждом; сфеноидные шипы снабжены в нижней части бугорном; нижная челюсть немного длиннее чем $1 / 3$ длины тела; иллициум приблизительно рявняется $1 / 12$ длины корпуса; эска - прозрачная, величиной в 1,5 раза диаметра глаза; она кроме вертикальных придатков имеет ещё 2 пигментированные боковые отростки; барбель имеет 2/3 длины тела, он раздвоен в конце, с двумя боковыми ветками на 2/3 его длины; концовые и. боковые ветии барбеля прозрачные, серого цвета, снабжены полукруглыми, мелкими сосочками, которые размещены в одном ряду; кожа черного цвета с бурым оттенком.

Address:

Mgr Leonard Ejsymont

Katedra Ichtiologii

Wyższej Szkoły Rolniczej

Szczecin, ul. Kazimierza Królewicza 4

Polska - Poland

Received 12.XI.1969 